\title{
The Lódź Congress and the Revival of the Polish Scouting and Guiding Association in 1956
}

\begin{abstract}
The "post-October" revival, so visible in the Polish society at the end of 1956, was clearly marked by the scouting group. The group had already shown some impatience and radicalism, as issues related to scouting had been waiting for solutions on the part of the authorities for a long time.

The congress in Łódź reactivated scouting. At the same time, it showed that everything that was happening inside the organization was nothing but a reflection of the processes taking place in society. The so-called October revolution did not have much in common with a real revolution, the October transformation would be a better term, as only a slight correction of the political system took place. ZHP was still limited by the system and greatly influenced by politics. That is why the "freedom", regained in Łódź, turned out to be an illusion.
\end{abstract}

Keywords: Polish Scouting, Congress in Łódź 1956

The "post-October" revival, so visible in the Polish society at the end of 1956, was clearly marked by the scouting group. The group had already shown some impatience and radicalism, as issues related to scouting had been waiting for solutions on the part of the authorities for a long time. What were they waiting for? After all, the defeat of the Polish Youth Union and the Scouting Organization associated with it was more than obvious. The words of A. Kamiński, spoken immediately after the war, that scouting would become a pathetic parody if it was to be used for ad hoc political reasons proved to be true ${ }^{1}$. Was is also obvious to the authorities? The events which took place at the end of 1956 and the later history of scouting serve as the best illustration.

On November 22, a meeting was to take place gathering representatives of all voivodships. However, it was cancelled, which only increased the nervous atmosphere. The

\footnotetext{
${ }^{1}$ See: WACHOWICZ, B., Kamyk na szańcu. Gawęda o druhu Aleksandrze Kamińskim w stulecie urodzin, Warsaw 2002, p. 360.
} 
General Headquarters had been suspected of procrastination. There was enormous pressure on both sides. The situation of the scouting authorities, anointed by the state, became particularly disadvantageous, as it made them look bad. The so-called grass-rooters used this time to organize meetings, consolidate. These gatherings were often attended by persons who until that time had not been particularly welcome in the scouting environment, which worried, for example, W. Dewitzowa. At the end of 1956 she wrote that: this consolidation is accompanied by the growth of authority of former instructors among our staff, there is a sense that they are a force based in society. Dissatisfaction with the current poor management and frequently changed decisions of the current Headquarters is of great importance ${ }^{2}$. A. Kamiński stated that: there is a healthy, creative ferment in the so-called field which has really put scouts on their feet and has contributed to the creation of good working conditions. This grassroots ferment has been able to do plenty of good in the local environments, things that we could not agree on with the Headquarters. [...]Warsaw and the Headquarters have not been able to achieve the same level as the regions ${ }^{3}$. The communist government was slowly beginning to realise that it was losing scouting, despite its last attempts to create the Red Scouting Organisation (e.g. in Koszalin) ${ }^{4}$. It would also be farfetched to say that pre-war scouts were greeted with enthusiasm everywhere; their authority among the youth was a reason for envy and ordinary human resentment. These negative feelings were transferred to everything that was associated with pre-war scouting ${ }^{5}$.

After cancelling the November conference, invitations to a new meeting were sent out - on December 8, 1956. This conference was to deal with basic issues: the name of the organization, the badge, the hymn, etc. The term "The Scouting and Guiding Association of the Polish People's Republic" was proposed, but there was also a proposal to return to pre-war standards, except for the presence of the symbol of the pioneer flame on the lily of the Scouts Cross. The participants of the December meeting, however, were not, as expected by the Headquarters, voivodship commanders, but delegates, elected by individual units. This was done in order to include "grassroots" that knew all about field "work" and wanted to have their share in making decisions important for their organization ${ }^{6}$. However, it was not anticipated that the conference would have such significance. And this became clear almost on the eve of the opening, as demonstrated by the program of the meeting presented to the participants, in which the term the Polish Scouting and Guiding Association

\footnotetext{
${ }^{2}$ AGK, Spuścizna W. Dewitz, 1, npg., Untitled manuscript, b. d. quotation by: K. PERSAK, Odrodzenie harcerstwa w 1956 roku, Warsaw 1996, p. 137.

${ }^{3}$ National Congress of Scout Activists in Łódź. Resolutions, papers, voices in the discussion, Warsaw 1957, p. 37.

${ }^{4}$ MILleR, J., Decydujacy rok (Powstanie i działalność Koszalińskiej Choragwi Harcerstwa w okresie grudzień 1956 - grudzień 1957), Koszalin 1982.

5 ZAKRZEWSKA, Z., "Problemy i kontrowersje ideowo-polityczne w harcerstwie w jesieni 1956 roku. Próba analizy", Harcerstwo, 1986, no. 10.

${ }^{6}$ The composition of these delegations was as follows: 3 people from the voivodship headquarters, $5-7$ people elected by poviat headquarters, $3-5$ unit members and 2 former instructors not working in the scouting organization. See: Aleksander Kamiński's archive, 13, npg., Objectives and organizational assumptions of the National Conference of Scout Activists in Łódź, formerly: Re: K. PERSAK, op. cit., p. 140.
} 
(ZHP) was used. K. Persak proves, rightly so, that this decision was the result of despair of the General Headquarters (OHPL), which seeing its diminishing role in the transformation of scouting decided to "make a leap forward" by restoring the tradition and name of the Polish Scouting and Guiding Association, while maintaining the current ideological direction - education for socialism ${ }^{7}$. The despair of the Headquarters was even greater when the meeting was opened with the song "Wszystko co nasze Polsce oddamy...", and most of the delegates were decorated with traditional scout crosses, just like the hall in which the meeting was held ${ }^{8}$.

This raises the question of why was the Łódź conference considered crucial, since at that time scouting did not have a common face? After all, two other meetings were being held at the same time, almost "alternative" to the meeting in Łódź: a meeting of pre-war instructors, "inactive" in the 1950s, the so-called seniors, which took place in the apartment of A. Kamiński, and juniors, meeting in Warsaw (the National Conference of Young Polish Scouts). Which environment should represent the scouts, which one was the living tissue of the organism? Who should take the final decisions and would it coincide with the expectations of the authorities? These questions were partly answered by Kamiński, who was one of the guests invited to the meeting in Łódź. The author of "Kamienie na szaniec" said: I feel a lot of trust in me in this room and this compels me to honestly express my thoughts and reflections on the revival of scouting. He also said that OHPL was not the only organization which represented scouts, and other scouting circles should be included in the revolution which had been taking place ${ }^{9}$. Therefore, the Łódź Congress should not make any decisions independently, without negotiating them with others. He also reminded the delegates of the role of public opinion and the need to arbitrate representatives of the government and the Communist Party ${ }^{10}$. However, Kamiński's recommendations had little chance of being implemented, as OHPL activists were running out of time. As Z. Zakrzewska said on behalf of the General Headquarters at the opening of the meeting: We have gathered together in the days of the scouting revolution to jointly decide on its future direction, to create a team that will have the strength to bring this revolution to an end. An important, characteristic feature of the scout revolution is the fact that it is taking place inside the organization, that the breakthrough is made by people who are its members ${ }^{11}$. Kamiński's comments were, therefore, somewhat provoked by Zakrzewska's

${ }^{7}$ Ibidem, p. 141.

${ }^{8}$ Ibidem.

${ }^{9}$ Kamiński used words that may raise doubts and wonder today: "If anyone in this room or outside the room thought that there could be new scouting in Poland without communists or against communists, would be a complete madman. [...]" Was this a declaration of submission or a real assessment of the situation? See: National Congress of Activists, op. cit., p. 40.

10 " [...] A revolution is taking place in the scouting organization, but the scouting organization and the management of the scouting organization is only a certain element of the overall nationwide situation. In Poland, the shaping of public opinion has been taking place since the 8th Plenum. The public opinion is fermenting and expressing its demands." See: Ibidem, p. 33.

11 Ibidem, p. 19. 
speech. Nevertheless, many other phrases used in her paper were close to the truth, but also to self-criticism, typical of the system. For example, the remark that education cannot be based on lies or that it was pointless to promote atheistic education in a society of believers ${ }^{12}$. Zakrzewska's appeal to the traditions of pre-war scouting, without wrongheadedness and lies, and her words that the greatest achievements of scouting were its humanistic views concerning children, the ability to see their needs and passions, the ability to adapt educational work to them ${ }^{13}$, may also have been the result of the political thaw. Moreover, scouting showed young people how to enjoy life, gave them a sense of adventure, play, taught happiness, coexistence with nature. [...]Scouting taught them [...] the attitude of readiness, which used to be known as scouting service ${ }^{14}$. The Scouting Organization was negatively assessed by Zakrzewska, as well as the activity of the Headquarters, on behalf of which she spoke and finally submitted her resignation. The author of the paper paid a lot of attention to the issue of rehabilitation of ZHP and those of its members who in the post-war years were wronged, persecuted, harassed, deprived of job opportunities or imprisoned. Zakrzewska postulated a return to the old methodology or symbolism of the organization, which she treated as a natural thing, because, as A. Kamiński observed: the pre-war legend of ZHP is so strong and vital that it has to give direction to the development of scouting ${ }^{15}$.

Other participants of the congress spoke in a similar tone. The problems they raised can be divided into the following categories: how to reactivate scouting - either on the ruins of OHPL, or by creating a completely new organization (Scout Porębski, Scout Jacek Kuroń, Scout Alfons Zawada); how to deal with instructors - both pre-war and OHPL instructors (Scout Marian Wierzbiański, Scout Jerzy Gaj, Scout K. Koźniewski ${ }^{16}$, Scout Ferdynand Trapp, Scout A. Zawada); should scouting be a political or religious organization (Scout Jerzy Gaj, Scout Bronisław Zgoła, Scout J. Kuroń ${ }^{17}$, Scout Kazimierz

12 Ibidem, p. 19-10.

13 Ibidem, p. 23.

14 Ibidem.

15 Ibidem, p. 34.

${ }^{16}$ Koźniewski believed that those who were not educators by profession should leave scouting, because in practical work with the youth, they were of little help. However, this remark was aimed at pre-war scouts, mostly educated people, which cannot be said of post-war activists. One of the reasons for the failure of the Scouting Organization was the overburden with preparation of the staff. Koźniewski, however, argued in the following manner: "Educators understand this matter well, whereas those who are not educators often overlook it. Therefore, let me appeal to the scouting leaders: do not introduce all the former instructors of scouting to your new organization, although everyone should be honoured for their merits, everyone should be entered into the pantheon of the history of scouting, teams should be named in their honour and their photographs must be hung in rooms. However, only those who explicitly prove they are educators, that is, those for whom the good of a growing generation is more important than their own past, should be chosen for organizational work. [...] Scouting is not an institution that rehabilitates anyone, there are other social instances responsible for this." Quote from: Ibidem, p. 61

17 The words of Scout J. Kuroń are significant for the whole period. He believed that no-one should be raised without any ideology. J. Kuroń was a supporter of upbringing in the spirit of socialism. In 1956, no one specifically criticized or fought against socialism. Only distortions and errors were opposed, it was still believed 
Koźniewski, Scout Stanisław Dąbrowski, Scout A. Zawada); the attitude to tradition and scout symbols (Scout J. Gaj ${ }^{18}$, Scout K. Koźniewski, Scout Stanisław Dąbrowski, Scout Jerzy Wieczorek); the attitude towards other youth organizations (Scout B. Zgoła ${ }^{19}$ ); the age problem of scouts (Scout B. Zgoła, Scout J. Wieczorek); the manner of appointing scout authorities - appointment or election (Scout B. Zgoła); cooperation between ZHP and schools (Scout K. Koźniewski); criticism of nationalism and anti-Semitism in prewar scouting (Scout St. Dąbrowski); abstinence among scouts (Scout J. Wieczorek, Scout Janusz Jędrachowicz). However, there was no detailed pedagogical reflection ...

After such words and declarations, even the members of the Headquarters must have realized that this was not an ordinary congress ... One of the participants even stated: I must admit I am a bit upset with the organizers of the congress, that we were not informed about its character and therefore were not able to prepare for it and notify the scouts that a significant, extremely important event was taking place on a national scale, which would determine the organizational basis of ZHP, and that the composition of the authorities of the Association was to be elected. If we had known about it - we would not have come in such a small number, but in a much larger group ${ }^{20}$.

Despite Kamiński's doubts ${ }^{21}$, the congress also decided to invite all his guests and the delegations from Warsaw (nineteen - the number of voivodships). The enthusiasm of the participants was so great that there was even a proposal to consider the congress as the

that socialism, especially with a "human face", is a blessing for humanity. Another participant of the meeting, Scout K. Koźniewski, made a similar statement: "It is not indifferent to us in which direction we will be steering the youth and children with the help of the cross, the lily, games and camps. As proved by history, this direction can be very diverse. The scouting method is the key to many locks. We want to open the door leading to the road to socialism, not any other." Quote from: Ibidem, p. 59.

$18 \mathrm{~J}$. Gaj represented the typical way of perceiving the scout tradition by OHPL activists, when he stated: "Returning to the old forms of the Polish Scouting Association is the right thing to do. We do not have new, clear forms of work, attractive forms, that would appeal to children and youth. Therefore, a general return to the progressive forms of the Polish Scouting Association is better. And not only to the forms of work, but also to the content of ZHP. If we refer to ZHP's forms of work, then these attempts should be clear and honest, so as not to cause more confusion. There was an attempt made to introduce a cross with a flame badge. Let's bring back the scout cross, the lily, and this will help in scouting work." Quote from: Ibidem, p. 50.

19 The following words were mentioned in this regard: "In scouting, educational work should be focused on inspiring love for the fatherland among the youth. A scout organization should be a completely independent and sovereign organization. Cooperation with other organizations can only be arranged on the idea of equality. In the nationwide educational system, the scouting organization should have a strictly defined place, equivalent to other social and educational factors." Quote from: Ibidem, p. 52-53

20 Ibidem, p. 48.

${ }^{21}$ Kamiński was not a supporter of quick action and quick decision-making. He wanted his guests first to "enjoy" their meeting and agree on their views, and only then to attend the congress. He proposed Monday as the day of the meeting. His doubts were also multiplied by fears that in order to work in the revived scouting organization: "only certain gems will have to be chosen, which are in harmony with the current political line of scouting and the political life. [...] And yet, it must be said that even taking into consideration the different moods of mistrust that prevailed among some scout instructors, we did not take any anti-state actions, aimed against the regime, against socialism. And that is why, as far as the instructors of the former ZHP are concerned, they deserve to be trusted, the party, the government and the society should trust them for their work in a reborn organization." See: Ibidem, p. 35. 
highest scouting authority, along with those who would arrive on the next day ${ }^{22}$. It was also decided to send a delegation with an invitation to the congress to the Central Committee of the Party and the Prime Minister. Kamiński refused this unexpected invitation by saying: As for those who will visit me, I will see most of them for the first time in 17 or 18 years old. I have not seen Tadeusz Strumilto, for example, since the war. I saw Grzesiak today for the first time after the war. I cannot come. I would like to fulfil these wishes, but that would mean we would come without really having though about any of this, and that would be exactly what the Headquarters would like us to do. And this should not be the case, because there cannot be only group that sets the direction. We need to allow other environments to think about it too. Until now, I have acted in these matters as a partisan. I was guided by emotions. But I want to consult this with people who have grown up with me in scouting for 30 years and you must allow me to do this ${ }^{23}$.

The invitation to Łódź was also a problem for scout activists meeting in the capital. They arrived at the convention on Sunday, after having held their short meetings, in the number of 50-80 people, which was more than the number proposed earlier. Everyone who arrived demanded full participation in the conference, which caused some tension with the OHPL activists. Their essence was the question of representation of both groups and their legitimacy to decide about the revival of ZHP. The OHPL congress considered itself fully legitimate and refused to review its resolution to invite only delegates from the Warsaw group. On the other hand, the scouts who came from Warsaw (known as the "Grey ranks" or - from the side number of the bus they came in - "Group 173"), were of the opinion that the delegates at the convention were elected undemocratically, according to an unknown key, that they were not social, but full-time activists, who had no right to appoint the organization's authorities. They believed that they, as representatives of various revolutionary scouting communities, had the right to represent $Z H P^{24}$.

The talks aimed at reaching a compromise were prolonged to such an extent that they lasted even after the end of the meeting in the main hall and after the draft resolutions and the list of candidates to the General Council were ready. There was a real danger of breaking the debate, especially since the voting was postponed until the dispute ended. Mediation was taken up by Minister W. Bieńkowski, who invited everyone present to listen to his speech on Sunday evening. He said: Scouting existed before the war, it existed during the occupation under very specific conditions and it existed in reborn Poland until 1948 and after 1948. The forms and conditions of social life imposed various ties on us, and the scouting organization was also prone to this. Was this situation determined by internal factors? No. This was determined by other factors. It was a historical necessity ${ }^{25}$. And then, [...] The problem of youth exists in every age and we have to work and look af-

22 The Library of the University of Warsaw, acc. 3560, ex., Fragment of the transcript of the Lódź Congress. Quote after: K. PERSAK, op. cit., p. 145.

${ }^{23}$ National Congress of Activists, op. cit., p. 39.

${ }^{24}$ Report of the deliberations of the Warsaw group, written by T. STRZEMBOSZ, 9 December 1956, J. Rossman's collection. Quote after: K. PERSAK, op. cit., p. 155.

${ }^{25}$ National Congress of Activists, op. cit., p. 89-90. 
ter youth in every age. Both at a time which is conducive to upbringing and at a time which is most unfavourable ${ }^{26}$. The Minister of Education also addressed the problem of the nature of changes that took place in Poland in the autumn of 1956, and made reflections on whether scouting is associated with the party, is it political, whether it should be associated with any party or be political. He concluded that like any social phenomenon, with a political meaning, it should and must be political, because being apolitical means indifference towards the society. Scouting is political in the sense that it is a form of education, interaction in the spirit of a certain general social and ideological attitude, that it is not indifferent to society ${ }^{27}$. Typical Marxist dialectic!

Minister Bieńkowski supported the idea of raising a particular type of citizen - a member of the society. What did that mean? He explained it in the following manner: We need to train the mind, shape the character, base upbringing on truth, on being active in relation to external life, to social phenomena. We want to raise an activist who will be able to give all his energy for the benefit of the society. We want to raise a patriot, a man who loves his country, a man who understands that he should give everything for his society and for his people. [...] We need to shape people who think and feel. Emotional attitude is undoubtedly important to us as the basis of our educational methods, if we want to reject the evil from the past methods, which denied the courage to see, the courage to speak, the courage to admit to the wrong or good; if we want to reject the conditions that shaped an internally twisted man, a man who was willing to compromise, who was hypocritical, who was willing to lie, who was ready for a whole range of discrepancies between internal attitude and external action ${ }^{28}$. The minister also encouraged greater discipline among the participants, which did not mean standing in attention all the time, but discipline based on awareness that the tasks of our country, of the working masses, of the entire nation, are extremely significant and that history has not given us much time to solve them. We must hurry. The period of Stalinism left us, as one of its sad legacies, with a deep demoralization of the society. One of the biggest concerns of the Party is to overcome this relaxation of discipline and to be aware of the tasks we have to undertake quickly. [...] Educational work is the basis of all transformations, all the changes affecting the society. Through upbringing, we enable our society to achieve the same results, which we achieve today with much more effort, more effectively, and at a lower cost. Only the proper upbringing of society can ensure that social energy is used for just and useful purposes ${ }^{29}$.

Bieńkowski's speech, full of lofty slogans and phrases, undoubtedly friendly to the scouts, was, however, a proof of political propaganda and clearly indicated the direction of changes in the organization, accepted by the state authorities. Despite the fact that the minister proposed to extend the debate for one more day, to include all the groups, his speech was not appreciated by delegates not belonging to OHPL. His friendly words were treated

\footnotetext{
${ }^{26}$ Ibidem, p. 90.

27 Ibidem, p. 92.

28 Ibidem, p. 93-94.

${ }^{29}$ Ibidem, p. 96-98.
} 
as an $\operatorname{order}^{30}$. The words of A. Kamiński, who spoke for the second time at the congress, sounded like an associating paper to the minister's speech. On the last day of the meeting he said: I do not want to conceal the fact that the genesis of this congress and its goal were not my idea. I believed and still believe that the revival of ZHP should take place, but the elements constituting the final decision should have been collected in a different manner. However, when yesterday the Minister of Education said that for the benefit of all parties, the revival of scouting should be based on the existing organization, it became clear to me and people who feel the same way that the minister's voice is decisive. [...] When we heard the minister's position yesterday, we understood it as an interpretation of the highest authorities. In line with our long-term view, we have to respond to this position and accept it with the best will, because we understood the speech of Minister Bieńkowski in the following way: People's Poland, after the October Revolution, needs our help. We are in danger of anarchy and deception in many areas of economic and social life. We cannot allow for disorder, for a devastating ferment in the education of youth [...]. Education is not going well. [...] We have the key to gain the trust and the hearts of young people. This key is scouting, authentic scouting. Let us do everything in our power to make the reborn scouting organization a positive experience, so that it absorbs everything that was creative and educative in the past scouting tradition, but in line with the life of society on a new road to socialism $^{31}$.

The composition of the meeting changed on the last day of the conference - on Monday, some delegates went home, despite the promises of Minister Bieńkowski to grant everyone working on that day a dismissal from work. Delegates from Warsaw and a group of Kamiński's seniors found themselves in the minority (about $10 \%$ of voters) ${ }^{32}$. This situation made the election atmosphere even more tense. The results turned out to be quite surprising: in principle, the participants voted for neutral people, who were not widely known, in order to prevent the election of more controversial persons. And thus, the composition of the 60-member Supreme Scouting Council (NRH) included: I. Chmieleńska, Z. Dąbrowski, M. Dobrzyńska, W. Grzelak, J. Haensel, K. Kalman, J. Kinast, B. Krasuski, F. Trapp, M. Wardęcki, Z. Zakrzewska (activists of OHPL), J. Grzesiak, A. Kamiński, D. Patora, S. Stipal, T. Strumiłło, W. Szczygieł, O. Żawrocki (the senior community) and Z. Skórzyńska (a group of "revolutionary scout youth"). The leaders of OHPL constituted the majority, which was to ensure the ideological leadership of the Party and the secularity of the reborn scouting organization ${ }^{33}$. NRH, thus constructed on December 18, 1956, elected the NRH Presidium. A. Kamiński was elected chairman. The head of the Scouting Headquarters was Z. Zakrzewska. Other agreements did not raise similar emotions and the resolutions were based on compromise. What was established?

${ }^{30}$ The order was even more dangerous because during the congress there were rumors that there were officers of the Security Service among the participants, and apparently even Roman Zambrowski himself.

${ }^{31}$ National Congress of Activists, op. cit., p. 99-100, 102.

32 Re: PERSAK, K., op. cit., p. 161.

${ }^{33}$ MAJKA, J., "Rola Związku Młodzieży Polskiej i jego aktywu w budowie zrębów Związku Harcerstwa Polskiego w latach 1955 - 1957”, Pokolenia, 1972, no. 2, p. 64. 
The Ideological Declaration of the Polish Scouting and Guiding Association stated: ZHP is a social organization gathering youth and instructors to work together for People's Poland. It is an ideological and educational organization based on scouting educational methods, enriched in accordance with the latest achievements of pedagogy ${ }^{34}$. It was also emphasized that ZHP is an independent body, as evidenced by its own program, statute and authorities. Scouting was to be a mass organization (a different kind of organization could not function in a communist state), which did not mean universality - being a scout was to be a matter of personal choice, based on the idea of voluntariness ${ }^{35}$.

The ideological leadership of scouting was to be designated by PZPR (the Polish United Workers' Party), which meant educating young people in the spirit of socialism. The model of an ideal man was, therefore, someone who is devoted to the struggle for the development and sovereignty of his Homeland, is a responsible host of his country, who knows how to work conscientiously and rule the country in a wise manner. For such a man the affairs of other nations were as important as the interests of his own people, he was to be sensitive to social injustice and defend human dignity, the weak, the victims and the persecuted. The ideal man was supposed to be a thinking man, with a bold and critical view of life, ready to improve it with his own efforts and active social attitude. He was also expected to act according to his viewpoint, be capable of sacrifice in the name of his ideas, to persistently fight for his own convictions, while respecting the views of other people. Finally, he was expected to consciously work on his own character and attitude ${ }^{36}$. It is interesting to observe that this ideal picture of the scout was promoted in the organization with great success, but it did not create a special enthusiasm on the part of the authorities.

In addition to general declarations, the congress also adopted specific resolutions. These included resolutions which brought back the identity of scouting. First of all, the former name of the organization was restored. The traditional scout cross became the official sign of ZHP (based on the virtuti military cross, referring to the ideals of heroism and patriotism and the struggle for the freedom and independence of the nation), and the song "Wszystko co nasze Polsce oddamy..." became the official hymn of the organization, the scout lily also regained its place. The scout salute was supposed to be a military one, as a tribute to national traditions, the scouts' greeting was a short "Czuwaj". ZHP was to "draw a brotherly hand" to Poles-scouts living abroad and establish contacts with other Scout organizations.

The following words were also included in the resolutions: ZHP draws its educational ideals from the most beautiful traditions of Polish culture, from the struggles of our nation for freedom, independence and progress, especially the heroic struggles of the working class, from the tradition of progressive youth movements in Poland, including the progressive movement of the entire scouting environment since the dawn of its existence, espe-

\footnotetext{
${ }^{34}$ National Congress of Activists ..., p. 5.

35 Ibidem.

${ }^{36}$ Ibidem, p. 6.
} 
cially the Grey Ranks. ZHP uses the achievements and experiences of pioneer organizations and other progressive youth organizations around the world by maintaining a deep bond with them. ZHP, as a secular institution, does not organize religious life. It educates its members in the spirit of freedom of conviction and broadly understood tolerance in relation to both believers and non-believers ${ }^{37}$.

Organizational decisions were also made in Łódź. And so, the Supreme Scouting Council (NRH) was appointed in the number of 60 people. NRH was to choose from among its members the General Headquarters, including the Head of Scouts (Z. Zakrzewska) and her deputies; the NRH Presidium was also appointed (the chairman was A. Kamiński). The authorities of the units and troops were also to be elected. In January 1958, the statutory ZHP Congress was to be convened, which was to adopt the statute of the Association and elect a new Supreme Scouting Council. The issue of co-education at ZHP was also to be addressed. The congress in Łódź also recommended organizing circles of scout friends, like before the war.

The congress in Łódź reactivated scouting. At the same time, it showed that everything that was happening inside the organization was nothing but a reflection of the processes taking place in society. The so-called October revolution did not have much in common with a real revolution, the October transformation would be a better term, as only a slight correction of the political system took place. ZHP was still limited by the system and greatly influenced by politics. That is why the "freedom", regained in Łódź, turned out to be an illusion.

\section{Bibliography}

MAJKA, J., „Rola Związku Młodzieży Polskiej i jego aktywu w budowie zrębów Związku Harcerstwa Polskiego w latach 1955-1957, Pokolenia, 1972, no.2.

MILlER, J., Decydujący rok (Powstanie i działalność Koszalińskiej Choragwi Harcerstwa w pkresie grudzień 1956 - grudzień 1957), Koszalin 1982.

National Congress of Scouts Activists in Łódź. Resolutions, papers, voices in the discussion, Warsaw 1957.

PERSAK, K., Odrodzenie harcerstwa w 1956 roku, Warsaw 1996.

WACHOWICZ, B., Kamyk na szańcu. Gawęda o druhu Aleksandrze Kamińskim w stulecie urodzin, Warsaw 2002.

ZAKRZEWSKA, Z., „Problemy i kontrowersje ideowo - polityczne w harcerstwie w jesieni 1956 roku. Próba analizy", Harcerstwo, 1986, no. 10.

Originally published in "Biuletyn Historii Wychowania", 2005/2006, vol. 21-22, pp. 95-104

${ }^{37}$ Ibidem, p. 6-7. 